\title{
Authentic learning in teaching Economics
}

\author{
Rochelle S. Serbo and Inero V. Ancho \\ Philippine Normal University, Philippines \\ Corresponding author: ancho.iv@pnu.edu.ph \\ DOI: https://doi.org/10.37134/jrpptte.vol9.no1.1.2019
}

Received: 11 February 2019; Accepted: 12 May 2019; Published: 17 June 2019

\begin{abstract}
Economics should impart training in the principles of economics, its application to different life situations and finally to help the student in understanding the basics of national economic environment because it will affect their lives as well. Authentic learning when applied in teaching Economics can make a difference on how the students view it as a subject. As learners in Economics classrooms develop 21st-century skills or competencies to live well in today's fast-paced society, they need opportunities to see themselves and their learning in a larger authentic context. Primarily, this study aimed to identify the authentic learning strategies and assessment used by Grade 9 Economics teachers. Specifically, this study sought to answer the following questions: 1 . What are the less authentic and more authentic learning strategies of Grade 9 Economics teachers?; 2. What are the authentic assessments being utilized by the Grade 9 Economics teachers? 3. Based on the findings of the study, what authentic learning teacher's guide for Economics can be developed and proposed? This qualitative- descriptive study aimed to identify the authentic instructional strategies and assessment of Grade 9 Economics teachers. A total of twenty (20) Grade 9 Economics teachers from San Jose del Monte, Bulacan and Quezon City in the Philippines participated in the research. In the end, a proposed teaching guide was developed which included authentic strategy and assessment based on the data gathered from the respondents. This guide contained suggested strategies, assessment and activities for each learning competency per quarter of the school year.
\end{abstract}

Keywords: Authentic learning, curriculum, economics, social studies, strategies

\section{Introduction}

A $21^{\text {st }}$ century education graduate is a lifelong learner with the generic skills of critical and higher order thinking skills, globally competitive and digitally literate. Traditional teaching approaches may not completely produce such standards and competencies among learners of today. Green (2010) argued that the $21^{\text {st }}$ century education must effectively prepare students to possess contemporary and reasonably competencies needed for productivity which includes skills like creative problem solving, collaboration, global mindedness and effectively digital technologies. Voogt and Roblin (2010) as cited by Inocian (2015) also added that the $21^{\text {st }}$ century skills are lifelong learning, competences needed in the struggle for personal life.The $\mathrm{K}$ to 12 program aims 
to prepare Filipino graduates to be globally competitive with the lifelong skills that are required for future employment. Dede, Korte, Nelson, Valdez and Ward, 2005 defined being a globally competitive graduate, a learner must be confident in dealing with the complex realities of the world situations. If exposed to such authentic environments, students can be more prepared to face the complexities of the requirements when they become professionals.

Many researchers Gonzales, Andrade, Civil, Moll, 2001; Skovsmose and Valero, 2002; Civil, 2002 as cited by Althauser and Harter (2016) supported the idea that education when based on students' experiences, needs and problems, it could be transformative in nature. Through active and authentic learning, an enjoyable, interesting and meaningful learning atmosphere can be created which Quintero (2007) called as "true learning". Mims (2003) agreed that authentic learning offers teachers strategies to bring the outside world inside the classroom. Through this, teachers will be empowered to transfer knowledge and skill into the everyday lives of the students outside the school which is then the true value of learning. Althauser and Harter (2016) also claimed that authentic instruction could be effective in improving students' achievement. If this will be an approach in the curriculum of the Philippine secondary public schools, there may be a difference in what kind of graduates it produces. $21^{\text {st }}$ century graduates must be real-life ready.

The curriculum for High School Social Studies (DepEd Conceptual Framework, 2012) as cited by Inocian (2015) is designed to be taught in interdisciplinary, multidisciplinary, integrative, investigative, thematic, chronological, conceptual, and content oriented with emphasis on the development of the $21^{\text {st }}$ century skills in $4 \mathrm{C}$ 's such as critical thinking, communication, collaboration and creativity. Economics is a discipline directly related to human activities in creating and consuming wealth (Subhashini, 2014). The concepts and the theories being taught in Economics class remain as plain technical concepts written in books and unrelated or unapplied to students' life experiences. Students failed to connect the relation between the subjects being taught in school and the realities of the world. The failure of every teacher to connect inside to the outside world of the classroom is the failure of every student in dealing with the reality outside the four walls of the classroom which according to Chulkov \& Nizovtsev (2015) is the common problem in education.

Abbot (2014) defined authentic learning as an instructional technique that connects learners to the real world issues, problems, and applications. Authentic learning targets the acquisition of the learners' ability to learn real world skills and competencies for lifelong learning. Through authentic learning, students will be able to face realities of the world without hesitation and shock. Authentic learning also gives the students ideas of what they are going to face outside the classroom.

"Real world" learning experiences according to Cavanaugh (2004) as cited by Lombardi (2007) include service learning, apprenticeships, cooperative learning, job-shadowing, and internship experiences. Authentic learning activity should be planned and designed to enhance existing talents and experiences of the students so that they gain confidence and connecting personal to professional practice (Lombardi, 2007). Learning environment similar to real world environment should make students realize that their achievement stretch from the classroom towards the outside world. Authentic learning activities must bring classroom experiences and learnings to provide them what the real world really is. Mehlinger (1995) as cited by Mims (2003) believed that students in the $21^{\text {st }}$ century must not only learn facts but also must use such facts to reality. Authentic learning has the ability to let students touch their own motivation internally towards involving themselves to the world realities. School activities which are based on practices of real-life experiences offer authentic learning. The basics of listening, reading, writing, and viewing are traditional, and authentic learning offers that students felt it necessary to confront real world rather than intermediaries such as books (Schiro, 2013).

Being a crucial subject, Economics is oftentimes overlooked by many schools (Van Wyk, 2015). Economic education has the goal to go far beyond what students understand on basic 
principles of exposing learners to the learning environment and what they are experiencing. The pedagogy of teaching Economics, teachers contribute much on the attitude of the students on the subject. By providing basic economic concepts and applying it to the current issues, Economic educators are provides students a foundation on making students present their own opinion and decide on vital economic issues. The more concepts, that the students learn, the more is the tendency of the students to value the essence of the economics. If students do not get to learn economics they will probably never take interest in the economic issues and the economic world itself.

When teaching Economics, teachers often face problems on how they are going to make their students understand the economic phenomena, concepts and terms to the application to their everyday lives. To overcome such, teachers must discover and apply new teaching methods which are compatible to the needs, abilities and interests of the students (Vasiliki, Panagiota \& Maria, 2016).

Several research findings according to Woldab (2015) indicated that the traditional approach or the "chalk-and-talk" approach is the instructional strategies that are predominantly used in teaching economics. This ignores the students' views making them passive and creates a classroom dominated and controlled by the teacher and produce students with low interest on economics courses. Teaching Economics should not be viewed as a mere transmission or lecturing of knowledge about economic facts, principles and theories but should be based on previous knowledge and association, students will be able to understand their learning experiences through brain storming to synthesize the new information they acquired. Being a constructivist economics teacher, problem solving and inquiry-based activities is a requirement for the students to formulate and test their ideas, draws conclusions and inferences in a collaborative environment. In teaching Economics, instruction and construction are combined and they must be connected successfully. The teacher functions as a stimulator or motivator of curiousity and also acts as a resource person. $\mathrm{He}$ also acts as senior co-investigator, a guide, co-learner, and facilitator. In teaching Economics, the classroom according to Senapaty and Pradhan (2005) as mentioned by Woldab (2015) should no longer be a place where the teacher is the mere giver of information.

Anchored on Situated and Experiential learning theories, authentic learning is being connected to both of the learning theories. It engages students to directly experience and reflect on the deeper knowledge, skills, and values (Association for Experiential Education). Compared to traditional classroom situations where students tend to exposed themselves to a competition and remained uninvolved and unmotivated, in an experiential and situated learning, students have the chance to collaborate and cooperate with each other in a more structured approach. Pedagogy is designed to let the students directly experience what is a real-world problems and life situations. In this learning approaches, the teacher acts as a facilitator rather than a director of the teachinglearning process. Its focus is on the pedagogy and not on the product of learning. Instead of studying and reviewing a topic or read a textbook article, in an experiential learning students are motivated to learn on their personal experience related to the subject. Learning stages of doing, reflecting and applying must be present for the objective of situated and experiential learning to be achieved. Such stages are different and powerful than other learning models as cited by Vasiliki, Panagiota and Maria (2016).

Researchers have presented the essence of authentic learning experiences to 10 design elements which provides educators a useful checklist for any subject areas (Reeves, Herrington, \& Oliver, 2002). 1) Real-world relevance: An activity on authentic learning usually matches on realworld activities of the professionals in practice. The activity is more authentic when students work actively with the concepts and facts related to mimicking reality; 2) Ill-defined problem: Real-life challenges cannot be solved easily by applying what is learned in books or theories but it is open for multiple interpretations; 3) Sustained investigation: an authentic activity cannot be solved in a matter of a short period of time instead it is investigated by the learners within a sustained period and requires a matter of investment of time and resources; 4) Multiple sources and perspectives: 
Teachers do not provide a list of resources, instead authentic learning provides opportunity to examine the task from theoretical and practical perspectives using variety of resources, the students have gathered focusing on the relevant information; 5) Collaboration: Authenticity deals with collaboration and cooperation as what the real workplace does; 6) Reflection (metacognition): authenticity is concern with learners making choices and reflect on their choices themselves or in a group; 7) Interdisciplinary perspective: Authentic learning works across and within the curriculum to the different learning areas encouraging students to adopt and think in an interdisciplinary manner;8) Integrated assessment: In an authentic assessment concerns on the reflecting real-world evaluation processes; 9) Polished products: Conclusions in an authentic learning culminate on a creation of a whole product and not a mere substeps in preparation for something else and 10) Multiple interpretations and outcomes: Rather than having a single response or correct answer, authentic learning activities allow a diverse interpretations and solutions.

\section{METHODS}

Qualitative-descriptive method is the most applicable for this study aligning to the main objective of the researcher, that of identifying common practices and instructional strategies of Grade 9 Economics teachers. A semi-structured interview was utilized to gather the data needed for the study. The data gathered were organized and analyzed until significant core ideas were obtained using the authentic learning design elements (Reeves, Herrington \& Oliver, 2000). Based on the findings, the researcher developed and proposed a teacher's guide on authentic learning strategies in teaching Grade 9 Economics.

The two research sites were chosen to present a rural and urban Grade 9 Economics teachers strategies and assessments in teaching Economics, the City of San Jose del Monte, Bulacan representing the provincial or rural area and Quezon City, representing an urban setting.

Upon approval, the researchers set the schedule for interview as convenient to the respondents. On the approved date and time, the researchers visited the respondents where the respondents are convenient and proceeded to administer the semi-structured interview. Twenty (20) economics teachers were inbobled in the interview proper, the researchers gave a brief orientation about the study and the purpose of the interview. She also mentioned the mechanics of the interview to ensure smooth exchange of ideas. The duration of the interview ranged from 25 to 30 minutes. The researchers made use of audio recorder, with the knowledge of the respondents to make sure that everything will be transcribed. All interviews were properly documented both in writing and audio recording, and finally, minutes of the interactions was properly be transcribed verbatim.

After gathering all necessary the data within three weeks through the semi-structured interview, the data was transcribed. It was given to the respondents for member checking through sending the transcript via the social media upon particularly the messenger appliaction for member checking which is also known as respondent's validation. This rechecking ensures that the researchers accurately transcribed their viewpoints of the topic into words. They were encouraged to comment anything they wish to add in those transcriptions.

After the conduct of interview, the collected data are analyzed and transcribed distinctively. The researchers then read and re-read all the transcriptions for familiarization. Significant features were identified from the data that might lead to answering the research problems referred to as "coding". Next, possible core ideas were discovered by looking at the codes and entire data are set to identify significant broader patterns of meanings. All possible core ideas were written to avoid biases. The initial core ideas were then renamed and redefined if relevant to authentic learning approaches in teaching Economics; it was not necessarily presented to the experts since the main purpose of the core ideas was for enumerating core ideas 
on authentic learning strategies and assessments. After identifying the core ideas from the data gathered, the researchers started to do the write-up of the research findings. Figure 3 presented the process of data analysis used in this study.

After identifying core ideas from the responses on instructional strategies utilized by the respondents, these were categorized as less and more authentic using the authentic design elements checklist (Reeves, Herrington, \& Oliver, 2002). The checklist helped in creating an authentic assessment and or evaluates current activities for authenticity. Three master teachers from the Division of Quezon City assisted the researchers in scoring each strategy based on the checklist.

The proposed teacher's guide was content validated using the Likert Five Point Scale on Evaluation Form-Expert's Assessment Checklist (EAC) with revisions to include the authentic design elements (Reeves, Herrington, \& Oliver, 2002) by two experts in the field of Economics. One is a member of Philippine Normal University faculty and the other one is the master teacher in Araling Panlipunan (Social Studies).

\section{RESULTS AND DISCUSSION}

Since people are now facing a complex world facing economic challenges from left to right. Economics as a subject in school must be taught effectively. It encompasses the pedagogy of economics in relation to contents, methods and assessments. To better understand the world, it is requiring for an education of basic economic concepts and its application to the issues around. As students grow, economic attitudes and opinions must be well been shaped and are for sure have an influenced thoughts and actions over their lifetime starting from the elementary years. Despite the use of multiple-choice questions in all types of assessments in undergraduate economic courses, the general picture is that economists and teachers of economics use more effective and applicable assessments with tasks and practices that have been for some time employed in other subjects. Economic education is now shifting from emphasis on teaching that meets the students' needs to their current and future lives. The challenges and opportunities in economics teaching in the twentyfirst century and beyond focus on empowering students to use economic knowledge to daily lives. Because of the global challenges, economic educators must therefore educate students to be creative in becoming responsible citizens, effective change agents, and decision makers (Van Wyk, 2015).

\section{Instructional Strategies}

From the data derived from the participants through the interview, four core ideas emerged in connection with the instructional strategies of Grade 9 Economics teachers. These include: 1) Individual and Group Work; 2) Current Events Discussion; and 3) Application to Real Life.

\section{Individual and Group Work}

Students progress personally in a collaborative learning, while collectively working for a particular common target. They are accountable to each member of their group to one direction giving an opportunity to self-management. Collaborative process includes students organizing themselves in a class, exerting effort to gather various resources for them to complete the task given; activities are usually not monitored by the teachers to encourage self-learning; students apply self and peer assessment for their individual and group activities and the outcome of the activity depends on the individual strengths not as a group.

Economics is good particularly if ICT is utilized so they can watch videos. That is what is important nowadays as we relay our lessons internationally. Most of the students are exposed to social media 
particularly facebook. They are looking for the trending issues which are not necessarily economic in nature. (Teacher $C$ )

While in a cooperative learning, students are interdependent to each other, they act particular negotiable roles and responsibilities. In a cooperative learning structure, it takes the following forms: 1) each student has specific role to play as assigned by the task given; 2) the teachers are responsible to present information for the students to read and analyze; 3 ) the teachers act as observers and intervene only if necessary; 4) students accomplish tasks at the end of the activity for assessment and 5) the success of the activity or tasks depends on the group effort.

When I do games, for example we are talking about prices for the topic savings. I do the groupings based on prices (P5, P15, P20, P25, P30). I will present situation based on the 7 habits of a wise saver and when I mention the price assigned to them, they will react to the situation. (Teacher F).

Teachers usually use collaborative and cooperative strategy in teaching Economics such as role playing, group activities and reporting. They also integrate technology in teaching as well as games. The findings showed that majority of the instructional strategies utilized by the teachers are more authentic. Based on the authentic checklist, majority of the strategies has authentic elements on real-world relevance, multiple sources and perspectives, collaboration, reflection, interdisciplinary and has multiple interpretations and outcomes. It seemed to present an idea that Economics teachers are utilizing authentic learning in their class through individual and collaborative activities.

\section{Current Events Discussion}

Current events that are happening in and out of the classroom provide authentic learning experiences for all grade levels. It provides the students and teachers the opportunity to examine multiple perspectives about the information available.

In discussing current events, students are comfortable in presenting their ideas in the classroom Perceiving and presenting the different sides of the story that allow the students to potentially develop civic participation. However, behaviors and perspectives of the wider culture also mediate the effects of classroom climate.

In an authentic learning environment, students must know what is happening in the world around them and it is the duty of the teacher to prepare them to face the realities of the world. The teacher must also take care in dealing and exposing students to the controversial current events without disregarding to nurture them developmentally (Wolpert-Gawron, 2017).

What I do is that I always tell them to watch the news every day. They do not know who will do the news report the following day because it is draw lots. You are all required. And if you are chosen and you are not ready, automatically you do have news. News reporting is essential in Social Studies. It is necessary to be updated particularly in Economics since it changes from time to time. (Teacher I)

By bringing the world into the classroom, through the use of current events, teachers have an opportunity to show students how what they learn actually matters in the world today. They can open their students' minds to different perspectives and experiences while still staying on track with the curriculum. It is possible, and helps make learning relevant. Current events have the ability to act as teaching moments. They cover issues in society which may not always work their way into the standard curriculum, yet teachers want to expose their students to. Not only are teachers trying 
to teach students a body of knowledge, but they are also teaching how to be well-functioning members of society. Current events is one way to help open students' minds to ideas of multiculturalism and discrimination. If the teachers deliberately keep the discussion going in a constructive direction, teachers can promote a greater understanding of differences amongst people.

There is, particularly at present. There are topics that you could connect in present times particularly the status of our economy, getting poorer and poorer. (Teacher $\mathrm{R}$ )

Being aware of the global issues is getting more important across the countries in the world. With the discussion of current events, students must understand world's economy, politics, social structure, and environment to make them capable of organizing good decision about how to live after graduating. This also includes domestic news which can enhance democratic ideals. Appreciating news and current events keeps track towards selfempowerment and advancement as well (Rink, 2016).

Rink (2016) also presented the benefits of teaching current events in class: 1) it allows students to discuss ideas within and across the curriculum; 2) it enhances communication skills; 3) it can help develop globally aware students to become informed citizens and lifelong news readers; helping them understand people, events and issues. It can stimulate students to further explore the news; 4) Current events can also serve as model for aspiring news writers; 5) it can also help the teachers teach media lit eracy skills in validating news information and data; 6) communication line can be open for both the students as well as their parents which could enhance their adult conversation skills as well and 7) current events discussion can also offer opportunities for group work and classroom performance tasks. It is the job of the educators to teach the students the skills to distinguish fact, fiction, and plain old opinion; they must also learn how to identify research or evidencebased statements or plain hearsays, not just "factoids" from Facebook, Twitter, or other fake information feeds that may sound like facts (Rink, 2016).

\section{Application to Real Life}

The daily life of the students is connected to what is happening in the world of economics. Grade 9 students taking up Economics as one of the social sciences in high school could have many economic information and misinformation. They are already exposed to making choices, spending, saving, or borrowing. They also act as participants when their family talks about spending and saving decisions. They are also affected by unemployment or inflation within their homes and communities. Through the exposure to the print or social media as well, they are already aware of the economic issues in the environment (Suiter, 2004).

For example, when we are talking about income. So that is where we relate. Example, what is your father's occupation? Sometimes, my students cannot understand themselves because they have not experienced, they have not experienced those kinds of lessons in their real life. Sometimes if you ask them they cannot have the so-called critical thinking. If there are those who experienced it, they could understand. (Teacher D)

Suiter (2004) also added that with the link between students' economic lives and school lives provides the real world connections. The study of economics enhances the ability of the students to possess content and analytical skills for them to fully understand the complexities of 
the economic world. With such skills, students can critically analyze current and historical problems and issues as well. Real world connections when applied in a particular lesson provide students the idea of why they are learning concepts beyond schools.

\begin{abstract}
Almost all, that is the beauty of Economics, unlike History that you go back to the past, here you have real-life situation...For example, in demand, in supply, in inflation for example, it is trending that is why it is easy to apply, reality like demand and supply. (Teacher $\mathrm{H}$ )
\end{abstract}

Based on the findings, teaches usually use individual, collaborative and cooperative strategy in teaching Economics such as role playing, group activities and reporting. They also integrate technology in teaching as well as games. The findings showed that majority of the instructional strategies utilized by the teachers are more authentic. Based on the authentic checklist, majority of the strategies has authentic elements on real-world relevance, multiple sources and perspectives, collaboration, reflection, interdisciplinary and has multiple interpretations and outcomes. It seemed to present an idea that Economics teachers are utilizing authentic learning in their class through individual and collaborative activities.

The daily life of the students is connected to what is happening in the world of economics. Grade 9 students taking up Economics as one of the social sciences in high school could have many economic information and misinformation. They are already exposed to making choices, spending, saving, or borrowing. They also act as participants when their family talks about spending and saving decisions. They are also affected by unemployment or inflation within their homes and communities. Through the exposure to the print or social media as well, they are already aware of the economic issues in the environment (Suiter, 2004).

It can be felt or when you are discussing you ask them, have you seen the news on the rise of the price of the gasoline. The fare hike... As students, what would be your reaction on this, are you affected? So in Economics it is easy, because it is the real event in the society, in the economy and themselves. (Teacher $\mathrm{N}$ )

By bringing the world into the classroom, through the use of current events, teachers have an opportunity to show students how what they learn actually matters in the world today. They can open their students' minds to different perspectives and experiences while still staying on track with the curriculum. It is possible, and helps make learning relevant. Current events have the ability to act as teaching moments. They cover issues in society which may not always work their way into the standard curriculum, yet teachers want to expose their students to. The foundation is laid for them to become conscious and concerned citizens participating to the real world. Teachers are not only teaching students a body of knowledge but also they teach on how to be well-functioning members of the society. Current events discussion is one way to help students' minds of ideas of multiculturalism and discrimination. If the teachers deliberately keep the discussion going in a constructive direction, teachers can promote a greater understanding of differences amongst people.

Being aware of the global issues is getting more important across the countries in the world. With the discussion of current events, students must understand world's economy, politics, social structure, and environment to make them capable of organizing good decision about how to live after graduating. This also includes domestic news which can enhance democratic ideals. Appreciating news and current events keeps track towards selfempowerment and advancement as well (Rink, 2016). 
Especially inflation at present they know that already as well as savings...Because people experience it. There are students also who experienced it and it is not impossible that they could relate to it. Especially when they watch the news, but if they don't have, they really don't have. (Teacher L).

Based on the findings, an instructional strategy that directly connects or indirectly connects the lessons to real life or situation is found to be more authentic. When teachers present examples or situations that are real-world related, students are expected to response and participate more in class since they can personally link to the situation or problem presented in class. Suiter (2004) also added that with the link between students' economic lives and school lives provides the real world connections. The study of economics enhances the ability of the students to possess content and analytical skills for them to fully understand the complexities of the economic world. With such skills, students can critically analyze current and historical problems and issues as well.

The lesson that a teacher teaches must be relevant to a student life. If not, the students remain passive and disinterested since they cannot find relevance to to it. The main purpose that a student will have is to gain good grades without taking into considerations the connections of the lesson to his own life outside the class. Before giving the students any bulk of information, they must be informed first of the reason why they need to hear such information because students do not give any relevant attention to something they do not know what sense it gives to their daily lives. If the lesson and the classroom materials are related to their own personal world, they strive since it has practical relevance. They must be shown concrete examples and its relation to them to make the lesson less abstract and complicated to them (Alstad-Davies, 2014). If the class discusses about their own experiences, family values or beliefs and current events, it surely can bring out the expected responses from them.

\section{Authentic Learning Assessment}

The authentic learning assessments presented by the respondents were classified to low, medium or high authenticity based on the eight Deakin Graduate Learning Outcomes (DGLO) to create the 'Deakin Difference' in the courses offered at Deakin University. Integrating authentic assessment strategies is fundamental for realizing this vision of 'empowering learners for the jobs and skills of the future' (Sridharan \& Mustard, 2015). The GLO's are: 1) discipline-specific; 2) written communication; 3) oral communication; 4) digital literacy; 5) critical thinking; 6) problem-solving; 7) self-management; 8) teamwork; and 9) global management. The categories of assessment methods are appended for reference.

I am really fond of authentic performance. For example, my favorite is the information brochure. In the first grading, consumption is included in the last topic, consumer rights and all that, also consumer rights and responsibilities. (Teacher $\mathrm{A}$ )

Most of the assessments are commonly used by teachers inside the class. Such assessments can be utilized in almost all fields of study in the high school level. The findings shows that majority of the respondents are using authentic learning assessments which have a high level of authenticity based on the Deakin University's Graduate Learning outcomes (Sridharan \& Mustard, 2015). This implies that Economic teachers are aware of their responsibility to relate their lessons to the real world for the students to be globally aware and lifelong learners. 
Best practice that I did was when we had the Eco Exhibit, we did an exhibit. They made different recycled materials. I asked them to make for example newspaper into a bag, zesto juice tetra bag into something else. (Teacher P)

The proposed teacher's guide includes authentic strategy and assessment based on the data gathered from the respondents. This guide is intended for the Grade 9 teachers who are teaching Economics in the junior high school level. This guide contains suggested strategies, assessment and activities for each learning competency per quarter of the school year.

The guide was developed based on the instructional strategies and assessments of the participants of the study. Sample lesson plans of the respondents were also used to guide some of the activities in the guide. Sridharan and Mustard (2015) assessment method guide also served as basis on choosing assessments which are high in authenticity.

It is just a simple guide which the Grade 9 Economics teachers can use for quick reference of authentic learning strategies, assessments and activities. It is entirely different to the guides provided by the Department of Education which is a detailed one. Since authentic learning requires multiple perspectives and interpretations, the answers to suggested activities' were not included since most of the activities' answers are subjective to the opinion and point of views of the learners and the educators.

The guide covers the four quarters in a school year. It contains a title page, preface describing the purpose of the guide, table of contents, and table presenting the main content of the guide which is the authentic strategies and assessment which serves as a quick guide for Economics teaching. The table has five columns, the first column contains the learning competency set by the Department of Education and its code; second column contains the suggested authentic learning strategy; third column contains suggested authentic assessment which can be utilized to achieve the learning competencies; and fourth column contains the suggested activities which may provide an alternative activity in achieving real-life learning among the Grade 9 learners. Such authentic learning provides sample strategies, assessment and main activity that a teacher may use in meeting the learning competencies. Most of the activities were derived from the respondents sample activities in their lesson logs enhanced and further developed by the researchers.

\section{CONCLUSIONS AND RECOMMENDATIONS}

As learners in Economics classrooms develop 21st-century skills or competencies to live well in today's fast-paced society, they need opportunities to see themselves and their learning in a larger authentic context. Economics teachers are aware of this challenge. This was evidently suggested by the findings of the study. Further, the researchers arrived at the following conclusions and recommendations:

1. Economic teachers are usually utilizing individual and collaborative real-life related instructional strategies. Current events discussion is an important strategy in teaching students to value global awareness and lifelong learning. Real life examples and situations as presented in class can make students value and appreciate the connections of Economics to their lives.

2. Using authentic assessment in teaching Economics serves as tools in assessing the students' understanding and appreciation of the theories and concepts learned inside the classroom as they linked it to the realities of the world.

3. Economics and other field of Social Sciences should utilize varied collaborative and cooperative activities for authenticity of instructional strategies and assessment.

4. Dissemination of information on varied authentic assessments for utilization in Economic instruction and other disciplines. 


\section{References}

Alstad-Davies, C. (2014). How to use real-life connections in the classroom to increase engagement. Retrieved from https://resumes-for-teachers.com/blog/interview-questions/excellentteachers-use-real-life-connections-in-the-classroom/

Althauser, K. \& Harter, C. (2016). Math and Economics: Implementing authentic instruction in Grades k-5. Journal of Education and Training Studies, 4 (4). 111-122.

Chulkov, D. \& Nizovtsev, D. (2015). Problem - based learning in managerial Economics with an integrated case study. Journal of Economics and Economic Educational Research, 16 (1), 188-197.

Dede, C., Korte, S., Nelson, R., Valdez, G., \& Ward, D.J. (2005). Transforming learning for the $21^{\text {st }}$ century: An economic imperative. Naperville, IL: Learning Point Associates.

Green, B. (2010). Authentic learning methods: a pillar of SMART education. Plymouth State University.

Retrieved

from http://theeffectiveeducator.wikispaces.com/file/view/A+L+Methods.pdf

Inocian, R. (2015). $21^{\text {st }}$ century skills in teaching Economics: K to 12 spiral instructional modeling (SIM) in the Philippines. Asia Pacific Journal of Education, Arts and Sciences, 2 (4), 111.

Lombardi, M.M. (2007). Approaches that work. How authentic learning is transforming higher education. EDUCAUSE, Retrieved from http://net.educause.edu/ir/library/pdf/eli3013.pdf

Mims, C. (2003). Authentic learning: a practical introduction and guide for implementation. Meridian: A Middle School. Computer Technologies Journal, 6(1), 1-5.

Reeves, T. C., Herrington, J., \& Oliver, R. (2002). Authentic activities and online learning. Annual Conference Proceedings of Higher Education Research and Development Society of Australasia. Perth, Australia.

Rink, T. (2016). Current events and why we need to them! Retrieved from http://blog.mimio.com/current- events-and-why-we-need-to-teach-them

Schiro, M.S. (2013). Curriculum theory, conflicting visions and enduring concerns. $2^{\text {nd }}$ Ed., Sage Publications Inc.,USA.

Sridharan, B., \& Mustard, J. (2015). Authentic assessment methods: a practical handbook for teaching staff part I and II. Deakin University: Australia

Subhashini, M. (2014). Teaching Economics: a reflection on learning centered approach. New Delhi. Retrieved from http://www/ncert.nic.in/announcements/oth_announcements/pdffiles/S.Muthukrishan.pdf

Suiter, M. (2004). Authentic teaching and assessment in Economics education, Retrieved from http://www.socialstudies.org/sites/default/files/publications/yl/1102/110204.html

Van Wyk, M. \& Alexander, J. (2010). Do teaching methods presented by the National Councilon Economics Education (USA) enhance trainers learning capacity in Economics Education? A South African Perspective Journal of Social Science, 23(3), 159 - 169. https://doi.org/10.1080/09718923.2010.11892825

Vasiliki B., Panagoita, K., Maria, S.K. (2016). New teaching method for teaching Economics in secondary education. IOSR Journal of Research and Method in Education, 6(2) 86 - 93.

Woldab, Z. (2013). Constructivist Didactics in Teaching Economics: A Shift in Paradigm to be Exemplary Teacher. Retrieved from http://www.mcser.org/journal/index.php/ajis/articles/viewFile/77/74.

Wolpert-Gawron, H. (2017). Teaching current events in the age of social media. Retrieved from https://www.edutopia.org/article/teaching-current-events-age-social-media 